\author{
Joanna Szczęsna \\ https://orcid.org/0000-0003-3824-7247 \\ Monika Wesołowska \\ https://orcid.org/0000-0002-6110-0270 \\ Maria Curie-Skłodowska University in Lublin \\ Faculty of Earth Sciences and Spatial Management \\ Institute of Socio-Economic Geography and Spatial Management \\ joanna.szczesna@poczta.umcs.lublin.pl \\ monika.wesolowska@poczta.umcs.lublin.pl
}

\title{
ASSESSMENT OF THE EFFECT OF NEW TOURISM PRODUCTS ON THE ECONOMIC RECOVERY OF RURAL AREAS IN THE CONTEXT OF EMPIRICAL RESEARCH ON SELECTED COMMUNES OF THE LUBLIN VOIVODESHIP
}

\begin{abstract}
This paper presents examples of several original tourism products available in the rural areas of the Lublin Voivodship (Eastern Poland) which in the context of empirical research have contributed to the development of tourism. The primary objective is to determine how selected tourism products are created, and their role in the development of the tourism function and local development in general. The article employs the case study method and concerns four tourism products in four communes of the Lublin Voivodeship. An assessment of the effect of the created product on local development was based on research employing a diagnostic survey in the form of a questionnaire and interviews. The interviews concerned the process of the creation of a tourism product and its effects was undertaken among entrepreneurs from the tourism industry, and the questionnaire concerning the effects of the resulting tourism product on local development was addressed to residents. The survey results showed that in each of the analysed cases, the creation of the tourism product could have considerably contributed to the development of the tourism function and economic development of rural areas where such products were created. Socio-economic phenomena accompanying the development of the tourism function are perceived as positive by residents of selected communes that see the development of tourism as a chance to improve their image and improve living conditions.
\end{abstract}

Keywords: rural areas, tourism product, Lublin Voivodeship.

\section{INTRODUCTION}

The modern development of rural areas, both in Poland and globally, takes three basic directions: 're-grounding' - reduction of expenditure on agricultural production and investment, and a search for new sources of income; 'deepening' - the production of high-quality food, including organic food, and 'broadening' - the appearance of new forms of activity, e.g. tourism (Halamska, Śpiewak, 2008). The internal potential of a region is considered as the basic development factor of a given area, and this includes tourism (Kuciński, 1994; Stanny, 2013). The development of tourism is directly determined by the occurrence and level of what has environmental and cultural value, tourism management, and transport accessibility (Lijewski, Mikułowski, Wyrzykowski, 2002;
Rogalewski, 1974). Butowski (2010) supplements this list of endogenic factors with promotion and tourism information, development and commercialisation of the tourism product, i.e. elements of territorial marketing as well as socio-economic, cultural, political, and ecological conditions (attitude of the local community towards tourists, activities of public authorities).

A smart village uses its strengths and resources for the development of new opportunities. According to Górka and Łuszczyk (2013), this concerns so-called high opportunity services, i.e. services with prospects for permanent development. Residents of a smart village implement specialisation in the scope of their tourism products (Portal Inteligentnych Wiosek, 2017). The introduction 
of the tourism function corresponds with the concept of village renewal and the multifunctional use of rural space. It can contribute to economic strengthening, comprehensive development, and an increase in the quality of life for village residents. It can also contribute to the revitalisation of rural areas. In the literature, research on the tourism function of rural areas shows that tourism can be a factor contributing to their socioeconomic activisation (Durydiwka, 2012).

One of the conditions for development of the tourism function is the creation of an interesting tourism product. Rural areas feature a high potential for the development of tourism products based on local space, nature, history or culture, or resulting from the observation of market needs or their creator's imagination. In the current period, the tourist searches for new sensations and emotions, modernity, surprise and wonder, the so-called the "wow" effect (Stasiak, 2013, 2015). Experience, knowledge, entertainment and emotions constitute a specific combination called the triad of tourism experiences, applied in creating the modern tourism offer (Stasiak, Włodarczyk, 2013).

This article presents an analysis of four original tourism products located in rural areas of the Lublin Voivodeship, the development of which, according to the respondents of the survey, has contributed to the development of the tourism function and considerable positive social and economic changes in the local environment. The objective of this study is the determination of the conditions for development of particular tourism products, an assessment of their effect on the tourism development of the analysed communes, and their role in local development overall.

The planned research tasks were implemented by means of a diagnostic survey in the form of a questionnaire and direct interviews in May 2018 in four communes of the Lublin Voivodeship. The interviews concerning the development of the tourism product and its effects was directed at those who had introduced a given product to the market, entrepreneurs from the tourism industry and institutions, and the survey concerning the effects of the developed tourism product on local development was directed at residents of the communes.

\section{THE TOURISM PRODUCT IN THE DEVELOPMENT OF THE TOURISM FUNCTION IN RURAL AREAS}

The tourism function comprises all socio-economic activity in a given location (village, region), directed at managing tourism, and resulting in the ability to meet specified tourism needs (Kurek, 2008). It is currently one of the basic non-agricultural functions developing in rural areas. It supports the process of comprehensive development, and is treated as a factor in socio-economic growth (Durydiwka, 2012; Kowalczyk, 2003; Sikorska-Wolak, 2007). Benefits resulting from the development of the tourism function in rural areas include diversification of sources of income for a commune, an increase in employment with greater opportunities for young people, an increase in the wealth of residents, infrastructural and economic development and the revitalisation of villages. The important role of tourism in rural development is confirmed by numerous EU financial support programmes. In recent years in the Lublin Voivodeship, tourism projects were financed e.g. from programmes such as Integrated Operational Programme Regional Development 2004-2006, Regional Operational Programme of the Lublin Voivodeship 2007-2013, Operational Programme Development of East Poland 2007-2013, and Rural Development Programme 2007-2013. The fact that tourism is an important aspect of the development of Polish rural areas is emphasised by the issue in 2015 of the national operational document "Programme for tourism development in rural areas in Poland" (Program rozwoju turystyki na obszarach wiejskich w Polsce, 2015), defining the objectives and vision of tourism development in rural areas, and characterising activities that should be implemented for its development.

The degree of development of the tourism function is determined by many factors. The most important one is considered to be tourism attractiveness, i.e. environmental or non-environmental features in an area determining the interest of tourists (Kurek, Mika, 2008). The basic element contributing to the tourism attractiveness of an area, and a necessary condition for development of the tourism function is the availability of tourism products.

In economic terms, a product is anything that can be introduced to the market, purchased, used or consumed, satisfying someone's wish or need (Kotler, 1994). A product is a group of benefits for the purchaser, a set of tangible and intangible useful properties, bringing functional, social and psychological benefits (Levitt, after Zdon-Korzeniowska, 2009). The tourism product comprises all goods and services created and purchased in relation to travel outside the place of permanent residence satisfying the various needs of tourists (Gołembski, 1998). Medlik (1995) distinguishes between tourist product sensu stricto, i.e. all that tourists buy, and tourist product sensu largo - a combination of what tourists do and the assets, facilities and services they use. It constitutes the whole experience, from the moment they leave home to the moment of return. With reference to this understanding of the concept of the tourist product, rural areas can offer both, product sensu stricto, in the form of objects, services, events, cultur- 
al products, tourism infrastructure, etc., and product sensu largo, adding a specific rural atmosphere and scenery to the offer, thus providing conditions for experiencing tourism in a unique way.

The range of tourism products that can be offered in rural areas is broad. Sznajder and Przezbórska (2004) divide them into nine categories: accommodation, gastronomy, agritourism, direct sale, recreation, sport, entertainment, therapy and ethnography. The list can be supplemented with many other elements such as the rural landscape and microclimate, nature, local history and its heroes, traditional craftsmanship and production, traditional architecture (residential, economic, sacred), archaeological sites, local lifestyle, etc. In addition to tourism products based on the authentic and traditional resources of rural areas, those with no relation are also encountered, resulting exclusively from their creators (e.g. amusement parks) or market demand (e.g. sports complexes).

Kruczek and Walas (2009) designate the enterprise tourism product, defined as a group of tourism services sold in travel agencies, and the tourism product of the destination, covering tourism attractions, infrastructure, services, image of the place in which tourism is implemented. In the cases described in this article, concerning tourism products offered in the rural areas of the Lublin Region, the latter type occurs, i.e. the tourism product of the destination.

According to the assessment of the European Network for Rural Development, in spite of the potential offered by permanent growth of tourism in Europe ( $3 \%$ annual increase in the number of tourists in recent years), the offer of rural tourism products is still relatively limited (European Network for Rural Development, 2019). Therefore, demand for creating original, interesting and diverse tourism products in rural areas meeting various needs of tourists is high.

\section{CHARACTERISTICS OF THE TOURISM PRODUCT OF SELECTED COMMUNES IN THE LUBLIN VOIVODESHIP}

This article presents the results of detailed research concerning four original tourism products in the rural areas of the Lublin Voivodeship. The products include: "Magic Gardens" in Trzcianka (Janowiec commune, Puławy poviat), "Nartsport" in Rąblów (Wąwolnica commune, Puławy poviat), “Goths' Village” in Masłomęcz (Hrubieszów commune, Hrubieszów poviat), and "Iron and Blacksmithing Traditions Trail" in Wojciechów (Wojciechów commune, Lublin poviat). They will be briefly presented further in the article.
"Magic Gardens" (Photo 1 and 2) is a family thematicsensory park based on fairy tales whose concept is an original idea of a private investor. The park has been in operation since 2014 and is dedicated to the individual tourist and families, and to school, pre-school and organised groups. Animators provide a guiding service. A souvenir shop is available on site (many souvenirs are personalised for the purposes of the park), as well as a restaurant and a cafe. Special and thematic events are organised there. Internet users rated the "Magic Gardens" as the greatest tourism attraction of the Lublin Region "Top attractions" in 2016 and 2017. The product was also awarded the Certificate of the Best Tourism Product in 2015, granted by the Polish Tourism Organisation.
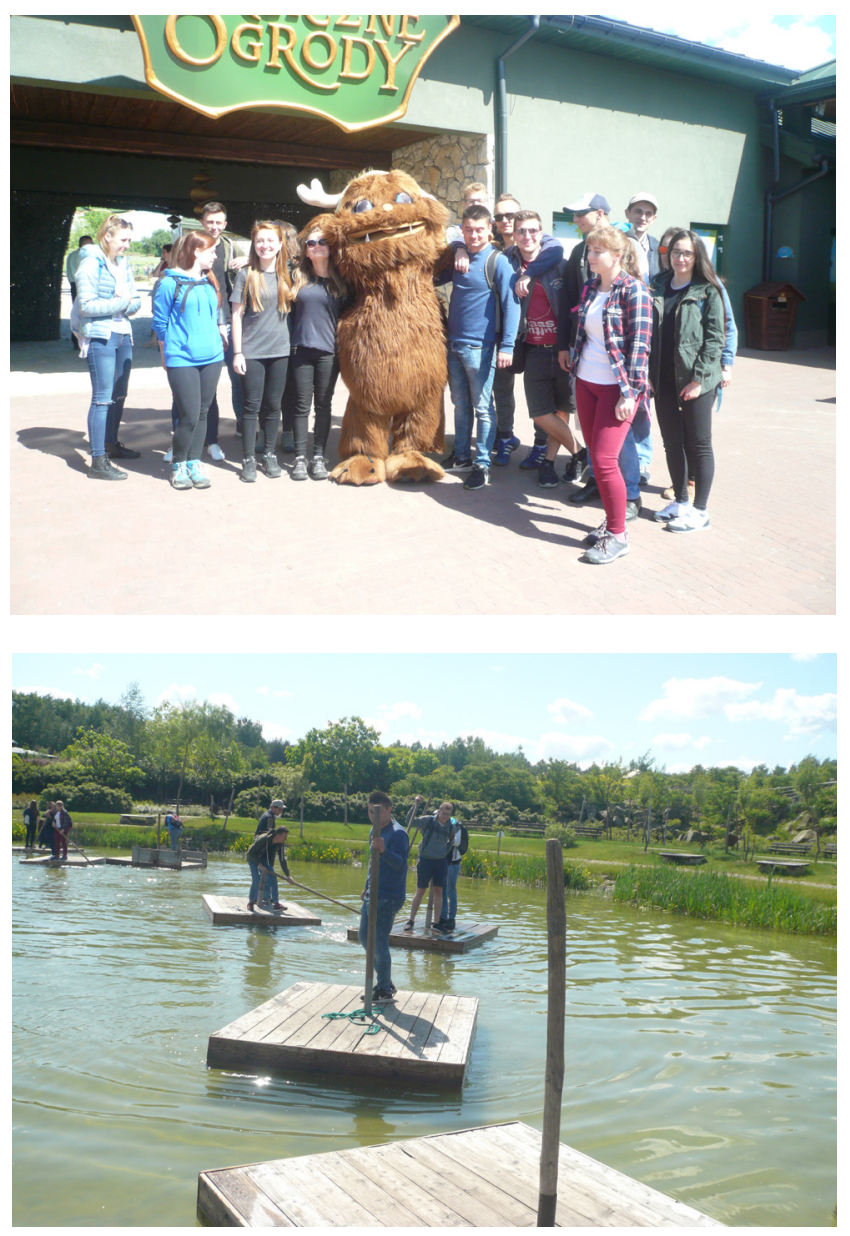

Photo 1 and 2. Thematic-sensory park "Magic Gardens" Source: M. Wesołowska

"Nartsport" (Photo 3 and 4) is a sports-recreational complex founded by a private investor. It was constructed in 1993 as the first ski lift in the Lublin Region, due to a very high demand for winter sports infrastructure. In the following years the offer was gradually expanded. Currently, in the winter season the product offers a skiing-snowboarding and sledging slope as well as equipment rental. In the summer season the offer covers 
swimming pools, jacuzzi, beach volleyball, playground and trampolines. Moreover, a restaurant is available for tourists along with a bar and accommodation. "Nartsport" hosts accompanying integration and special events.

"Goth Village"(Photo 5 and 6) is a historical-cultural reconstruction, created in 2008. Its idea is based on the archeological research conducted in the village since 1977. This research concerned Gothic culture, a tribe of Germanic origin that reached the Hrubieszów Basin in the $2^{\text {nd }}$ century. After the completion of the research, based on the initiative of local residents, the Masłomęcz Society "Goth Village" was established, with the primary objective of popularising knowledge of the cultural-historical heritage of the region, and the implementation of the "Gotania" Project. The society currently numbers 30 , and provides educational, academic, promotional, entertainment and business activities. The open-air museum features a presentation recreating the everyday life of the Goths, and offers workshops, "living" history lessons, cyclical reconstruction and thematic events (among others the Archaeological Feast), and academic and popular science conferences organised by the Society. "Goth Village" was recognised as the Best Tourism Product of the Lublin Voivodeship in the category "Object" in 2017.

"Iron and Blacksmithing Traditions Trail" (Photo 7 and 8 ) is an integrated public-private product, which was created by the gmina and some economic entities with reference to local blacksmiting traditions. The product consists of several components, such as: visiting the Museum of Blacksmithing and the currently working Roman Czernic»s smithy, a possibility to eat a traditional meal on an agritourist farm called „U Kowalowej", and melting and molding metals in a bloomery. Moreover, a tourist can visit the Regional Museum and participate in workshops and blacksmith events. In 2010, the "Iron and Blacksmith Tradition Trail" was awarded the Certificate of the Polish Tourism Organisation for the best tourism product. It also received
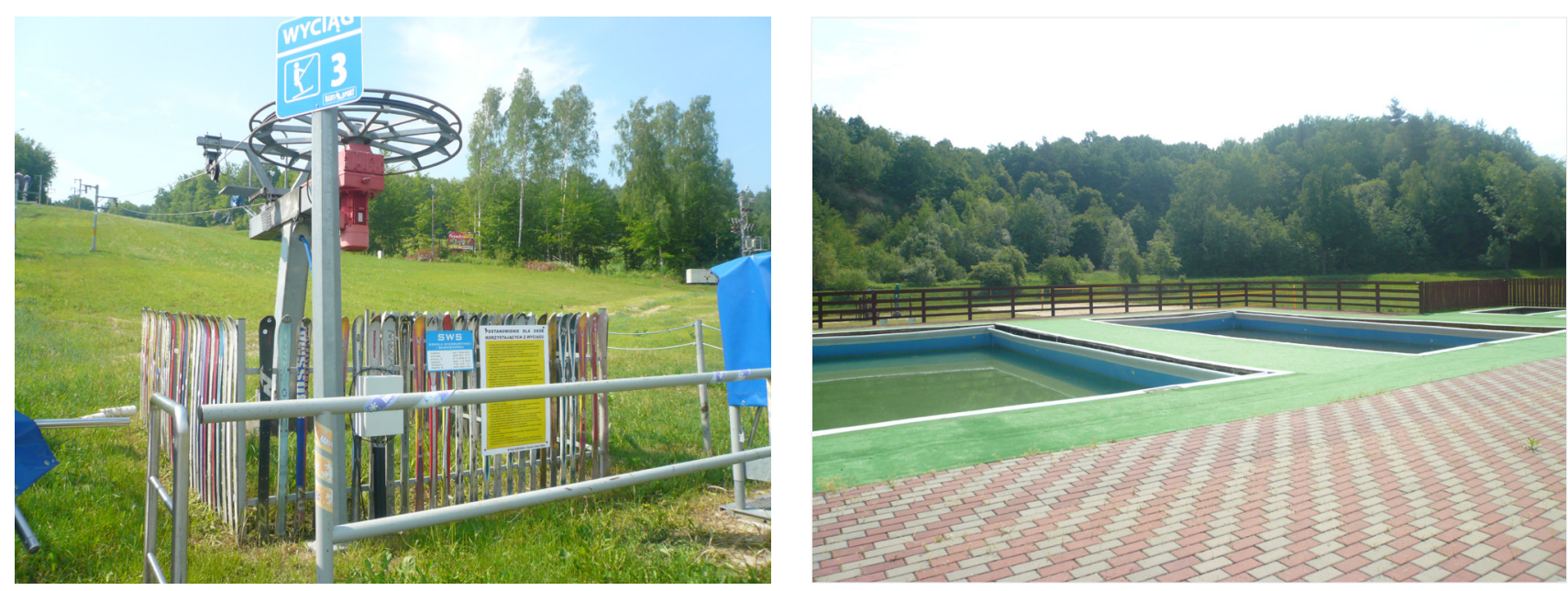

Photo 3 and 4. Sports-recreational complex "Nartsport" Source: M. Wesołowska
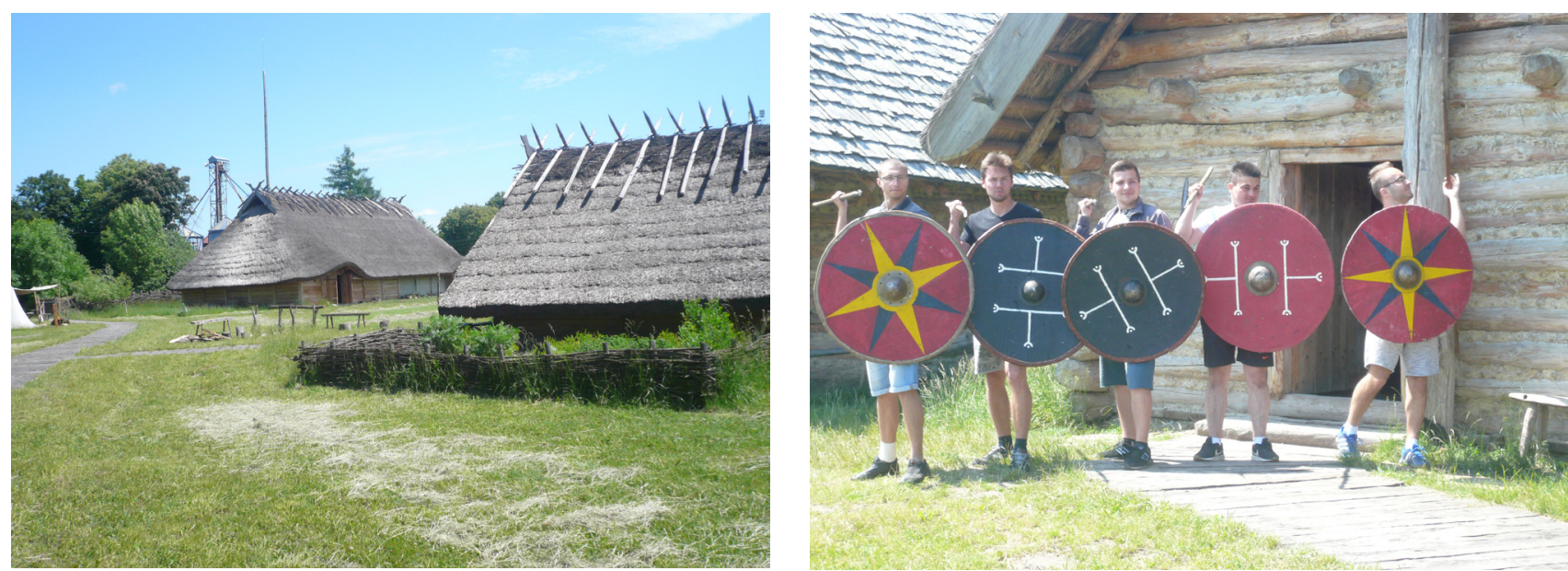

Photo 5 and 6. "Goth Village"

Source: M. Wesołowska 
the title of Peretka Lubelszczyzny (Pearl of the Lublin Region) in 2009, and third prize in a competition for the most interesting rural tourism package during the II International Fair of Rural Tourism and Agritourism, AGROTRAVEL Kielce 2010.
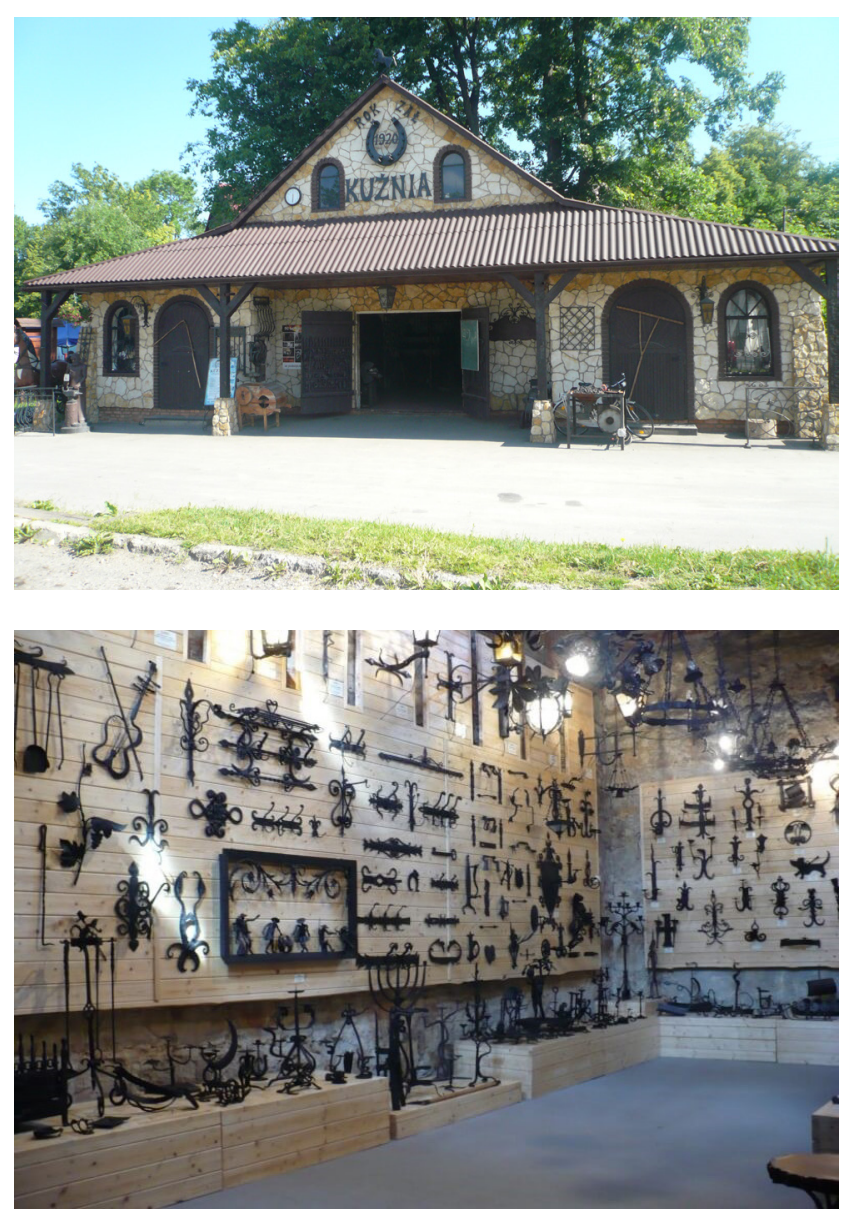

Photo 7 and 8. "Iron and Blacksmith Tradition Trail" Source: M. Wesołowska

\section{STUDY RESULTS}

The study was conducted in May 2018 in four communes of the Lublin Voivodeship employing a diagnostic survey (interview and questionnaire). The objective was to collect opinions on the effect of the development of a tourism product on the tourism function in communes, and an assessment of the effect of the tourism product on the local environment. The direct research (questionnaire) was based on a random sample of residents of particular communes. Responses were obtained from a total of 276 (Janowiec commune - 76 questionnaires, Hrubieszów - 78, Wąwolnica - 65, and Wojciechów - 57). In the case of entrepreneurs/ institutions running the selected tourism product, research in the form of a direct interview was used (four interviews).
The questionnaire directed to residents included 20 questions. First, respondents were asked to answer the question: Are you glad that the investment is in operation in this area? The majority of residents were satisfied with tourism investments implemented in the area (as much as three-quarters of respondents from Janowiec and Hrubieszów, somewhat less from the remaining communes) (Table 1). The respondents believe that the investment has improved the image of their communes. The residents themselves take more care of their premises, and owing to the investment, new roads and infrastructure have been constructed. The majority of residents in the surveyed communes were of the opinion that the investment has had a positive effect on the commune (Table 1) because it employs local residents (particularly in the tourism season), cooperates economically with the surrounding area, and conducts activities for the benefit of the commune (integration events, free access to services for residents, sponsoring). Owing to the investment, the commune is recognisable, and the product itself contributes to the promotion of the village where it is located. This is recognised to the greatest degree by residents of Wojciechów (Table 1).

The respondents (from 77 to $83 \%$ ) also believe that the investment has contributed to the economic development of the commune. This is confirmed by the fact that the main investment is accompanied by the development of other services and commerce aimed at tourists (e.g. production of souvenirs, accommodation, gastronomy, transport, sale of local products), the revival of traditional craftsmanship (pottery, smithery), and the appearance of new supplementary tourism attractions providing residents with higher profits resulting in the improvement of their economic situation.

A very high number of respondents (more than $80 \%$ ) believe that tourism contributes to the better development of communes, and would like them to develop in terms of tourism to a greater degree - the residents themselves point to many suggestions and ideas for activities that would support such development. The respondents generally assess the activity of commune local government in terms of tourism development quite negatively (Table 2). They point to a lack of training and incentives for residents in terms of the development of business activity, and the lack of financial support for investments. The respondents repeatedly complained about the gmina allocating insufficient means to tourism development and pointed out that new investments in tourism are more frequently private than public.

The second part of the research, in the form of interviews, was conducted among investors or representatives of institutions running a given tourism product. Their results permitted the formulation of the following conclusions.

All investors/organisers are satisfied with activities related to the tourism product, and think it is profitable. 
Table 1. Responses to questions concerning the effect of the tourism product on the area (\%)

\begin{tabular}{|c|c|c|c|c|c|c|c|c|c|c|}
\hline \multirow[t]{2}{*}{$\begin{array}{l}\text { Product } \\
\text { (commune) }\end{array}$} & \multicolumn{3}{|c|}{$\begin{array}{c}\text { Are you glad } \\
\text { that the investment } \\
\text { is in operation in the area? }\end{array}$} & \multicolumn{2}{|c|}{$\begin{array}{l}\text { Did the image } \\
\text { of the area improve } \\
\text { owing to the } \\
\text { activity of the object/ } \\
\text { attraction? }\end{array}$} & \multicolumn{3}{|c|}{$\begin{array}{l}\text { Do you think the investment } \\
\text { has an effect on the area? }\end{array}$} & \multicolumn{2}{|c|}{$\begin{array}{c}\text { Were other } \\
\text { companies } \\
\text { established } \\
\text { in the area owing } \\
\text { to its activity? }\end{array}$} \\
\hline & no & yes & $\begin{array}{c}\text { I am } \\
\text { indifferent }\end{array}$ & no & yes & no effect & $\begin{array}{c}\text { positive } \\
\text { effect }\end{array}$ & $\begin{array}{c}\text { negative } \\
\text { effect }\end{array}$ & no & yes \\
\hline $\begin{array}{l}\text { Magic Gardens } \\
\text { (Janowiec) }\end{array}$ & 11,7 & 74,0 & 14,3 & 34,2 & 65,8 & 22,1 & 63,6 & 14,3 & 74,7 & 25,3 \\
\hline $\begin{array}{l}\text { Goths' Village } \\
\text { (Hrubieszów) }\end{array}$ & 9,0 & 74,3 & 16,7 & 35,9 & 64,1 & 34,6 & 64,1 & 1,3 & 63,6 & 36,4 \\
\hline $\begin{array}{l}\text { Nartsport } \\
\text { (Wąwolnica) }\end{array}$ & 3,1 & 69,2 & 27,7 & 35,4 & 64,6 & 34,3 & 57,1 & 8,6 & 63,1 & 36,9 \\
\hline $\begin{array}{l}\text { Iron Trail } \\
\text { (Wojciechów) }\end{array}$ & 3,5 & 66,7 & 29,8 & 28,1 & 71,9 & 37,5 & 62,5 & 0,0 & 69,1 & 30,9 \\
\hline Average & 6,8 & 71,1 & 22,1 & 33,4 & 66,6 & 32,1 & 61,8 & 6,0 & 67,6 & 32,4 \\
\hline
\end{tabular}

Source: own research based on a survey.

Table 2. Responses to questions concerning the development of the tourism function in the commune (\%)

\begin{tabular}{|c|c|c|c|c|c|c|c|c|c|c|c|c|c|c|}
\hline \multirow[t]{2}{*}{$\begin{array}{l}\text { Product } \\
\text { (commune) }\end{array}$} & \multicolumn{2}{|c|}{$\begin{array}{l}\text { Would you } \\
\text { like the } \\
\text { commune } \\
\text { to develop } \\
\text { in terms of } \\
\text { tourism? }\end{array}$} & \multicolumn{2}{|c|}{$\begin{array}{l}\text { Would you } \\
\text { like other } \\
\text { tourism } \\
\text { investments } \\
\text { to be } \\
\text { implemented } \\
\text { in the area? }\end{array}$} & \multicolumn{2}{|c|}{$\begin{array}{l}\text { Does the } \\
\text { commune } \\
\text { undertake } \\
\text { any action } \\
\text { for the } \\
\text { development } \\
\text { of tourism } \\
\text { in the area? }\end{array}$} & \multicolumn{2}{|c|}{$\begin{array}{l}\text { Does } \\
\text { the commune } \\
\text { facilitate } \\
\text { the access } \\
\text { of residents } \\
\text { to funds } \\
\text { for tourism } \\
\text { development? }\end{array}$} & \multicolumn{2}{|c|}{$\begin{array}{l}\text { Does } \\
\text { the commune } \\
\text { encourage } \\
\text { residents } \\
\text { to invest } \\
\text { in tourism } \\
\text { development? }\end{array}$} & \multicolumn{2}{|c|}{$\begin{array}{l}\text { Are any training/ } \\
\text { educational } \\
\text { activities } \\
\text { concerning } \\
\text { development } \\
\text { of tourism } \\
\text { entrepreneurship } \\
\text { implemented } \\
\text { in the commune? }\end{array}$} & \multicolumn{2}{|c|}{$\begin{array}{l}\text { Do you think that } \\
\text { tourism deve- } \\
\text { lopment would } \\
\text { contribute } \\
\text { to the better } \\
\text { development } \\
\text { of the commune? }\end{array}$} \\
\hline & no & yes & no & yes & no & yes & no & yes & no & yes & no & yes & no & yes \\
\hline $\begin{array}{l}\text { Magic } \\
\text { Gardens } \\
\text { (Janowiec) }\end{array}$ & 18,4 & 81,6 & 25,0 & 75,0 & 52,0 & 48,0 & 60,8 & 39,2 & 63,3 & 36,7 & 74,7 & 25,3 & 20,0 & 80,0 \\
\hline $\begin{array}{l}\text { Goths' Village } \\
\text { (Hrubieszów) }\end{array}$ & 24,4 & 75,6 & 25,6 & 74,4 & 44,7 & 55,3 & 42,7 & 57,3 & 48,6 & 51,4 & 58,3 & 41,7 & 9,0 & 91,0 \\
\hline $\begin{array}{l}\text { Nartsport } \\
\text { (Wąwolnica) }\end{array}$ & 6,2 & 93,8 & 14,3 & 85,7 & 55,7 & 44,3 & 56,7 & 43,3 & 55,7 & 44,3 & 59,3 & 40,7 & 6,1 & 93,9 \\
\hline $\begin{array}{l}\text { Iron Trail } \\
\text { (Wojciechów) }\end{array}$ & 21,1 & 78,9 & 20,7 & 79,3 & 58,2 & 41,8 & 55,4 & 44,6 & 66,1 & 33,9 & 71,2 & 28,8 & 7,1 & 92,9 \\
\hline Average & 17,5 & 82,5 & 21,4 & 78,6 & 52,7 & 47,3 & 53,9 & 46,1 & 58,4 & 41,6 & 65,9 & 34,1 & 10,5 & 89,5 \\
\hline
\end{tabular}

Source: own research based on a survey.

Moreover, having knowledge of today's socio-economic reality, they would undertake the investment again. All the respondents are planning to develop their activity, although depending on the need for financial resources. Obtaining external funds will facilitate the development of investments. External funds would also be of high importance at the stage of the implementation of particular undertakings. The tourism products were implemented from their own resources and with EU assistance, and in the case of the "Goth Village" the entire investment was financed externally. All respondents confirmed that with no financial support the implementation of the tourism product would not have been possible.
According to the investors, this led to the launch of investment-generated tourism at a level from several to several tens of thousands of visitors annually. Unfortunately, citing the necessity for data protection, the investors did not agree to provide detailed information regarding the number of visitors. Based on interviews and direct observations in the field it can be presumed, however, that the highest number of tourists visit the "Magic Gardens" in Janowiec commune where the investment generates tourism at a level of several tens of thousands of visitors annually.

The interviewed entrepreneur/organisers encounter positive perceptions of the investment in the local 
environment, and observe a general increase in interest of the residents in the development of the tourism function in the commune. The positive reception is related to professional opportunities created by particular investments for the local community and particularly young people. Entrepreneurs employ (although mainly in the tourism season) and train employees particularly from the local environment. The "Magic Gardens" employ more than 100. Moreover, all the entrepreneurs/organisers cooperate with the local environment not only in the business sphere, but also in the non-business socially-oriented one, e.g. by organising integration events for residents, ensuring free access to the tourism attraction, and even sponsoring different kinds of activity for the local community.

The interviewed investors observe the positive effect of their activity on the development of entrepreneurship in the area. They set an example and incentive for residents to create and develop their own business ideas, and also to take care of the general image of their households and communes.

Similar to surveyed residents, the entrepreneurs/ organisers observe a need for greater involvement of local government in the development of the tourism function, particularly in terms of infrastructure as well as training and support for residents.

\section{SUMMARY}

The survey showed that in all the analysed communes the development of the tourism function occurred after the creation of an interesting tourism product. According to the opinion of the respondents in the survey, the products had a considerable effect on the recovery of tourism. The survey, concerning both the opinions of residents and entrepreneurs, as well as the observations of the authors, suggests the following conclusions:

1. the development of tourism has contributed to an increase in the economic level of communes and the development of local entrepreneurship, particularly in terms of commerce and services targeted at tourists;

2. investments related to the creation of particular tourism products are positively evaluated by the local community. Residents of the communes see the need for tourism development as a way of improving the economic situation. The development of tourism also provides professional opportunities for young people, in many cases contributing to a decision to remain in the place of residence, which in a situation of the out-migration of the young from rural areas is of considerable importance for the demographic future of villages. The seasonal character of the tourism industry in Poland, and the related time limitation for making a profit, however, is still problematic. A partial solution is the expansion and diversification of the offer of tourism products with consideration for the interests and needs of different groups of tourists, and the preparation of offers for different seasons. An example of a bi-seasonal offer, for winter and summer, is the sports-recreational complex "Nartsport" in Rąblów, and a multi-seasonal character is represented by the "Iron and Smithery Tradition Trail" and the "Goth Village";

3. tourism investments have a substantial effect on business and the social integration of the local rural environment, undertaking cooperation for the economic and general development of the commune. Other, positive effects of the implemented projects are also evident. They have contributed to the improvement of the aesthetic image of communes, and to the preservation and development of the cultural heritage of the analysed areas. Moreover, the identifiability and popularity of communes among visitors has increased, as well as the sense of pride of inhabitants concerning their place of residence and strengthening their local identity;

4. the weakest link in the process of tourism development is local government. According to both residents and organisers, the contribution of commune local governments in tourism investments is insufficient. The majority of implemented concepts are private, and based on the entrepreneurship and creativity of individual investors or institutions. Only the "Iron and Smithery Tradition Trail" is a commune-private project. Greater involvement of local government institutions in the education as well as consulting and financial support of residents, in terms of developing the tourism function, as well as the development of infrastructure, is also necessary,

5. the described tourism products are of local character and are not interconnected in a network of attractions located in different communes. No common tourism infrastructure exists either. Integrated, complementary products with an inter-commune character that could attract the tourist for a longer stay are definitely missing. This is another area requiring the involvement and coordination on the part of commune authorities, as well as cooperation between particular communes.

The analysis of these cases shows that creating an interesting tourism product can be a developmental factor for the tourism function in rural areas. It also contributes to their socio-economic development. The supply of this type of product, however, is still relatively low, and an increase requires conceptual, educational, and financial measures not only on the part of individual subjects, but particularly on the part of commune authorities. 


\section{REFERENCES}

Butowski, L. (2010). Turystyka jako czynnik rozwoju w świetle wybranych teorii rozwoju regionalnego. Turyzm/Tourism, 20 (1), 5-11.

Durydiwka, M. (2012). Czynniki rozwoju i zróżnicowanie funkcji turystycznej na obszarach wiejskich w Polsce. Warszawa: Uniwersytet Warszawski, Wydział Geografii i Studiów Regionalnych.

European Network for Rural Development (2019). Retrieved from: https://enrd.ec.europa.eu/ (28.06.2019).

Gołembski, G. (1998). Przedsiębiorstwo turystyczne w gospodarce wolnorynkowej. Poznań: Wydawnictwo Akademii Ekonomicznej.

Górka, K., Łuszczyk, M. (2013). Inteligentna specjalizacja czy raczej sektor "wysokiej szansy” atutem w rozwoju regionów. Studia KPZK PAN, CLV, 52-60.

Halamska, M., Śpiewak, R. (2008). Rozwój wiejski - nowa utopia czy konieczność? In: M. Drygas, A. Rosner (eds), Polska wieś i rolnictwo w Unii Europejskiej. Dylematy i kierunki przemian (pp. 393-416). Warszawa: IRWiR PAN.

Kotler, P. (1994). Marketing - analiza, planowanie, wdrażanie i kontrola. Warszawa: Gebethner i S-ka.

Kowalczyk, A. (2003). Tourism as a factor of local development. In: A. Kowalczyk (ed.), Geographical space at the turn of the century (pp. 217-222). Warszawa: Uniwersytet Warszawski, Wydział Geografii i Studiów Regionalnych.

Kuciński, K. (1994). Geografia ekonomiczna. Zarys teoretyczny. Warszawa: Wydawnictwo SGH.

Kurek, W. (ed.) (2008). Turystyka. Warszawa: Wydawnictwo Naukowe PWN.

Kurek, W., Mika, M. (2008). Turystyka jako przedmiot badań. In: W. Kurek (ed.), Turystyka (pp. 11-48). Warszawa: Wydawnictwo Naukowe PWN.

Lijewski, T., Mikułowski B., Wyrzykowski, J. (2002). Geografia turystyki Polski. Warszawa: PWE.
Medlik, S. (1995). Leksykon podróży, turystyki, hotelarstwa. Warszawa: Państwowe Wydawnictwo Naukowe.

Portal Inteligentnych Wiosek (2017). Retrieved from: https://enrd. ec.europa.eu/smart-and-competitive-rural-areas/smart-villages/smart-villages-portal_pl (20.09.2018).

Program rozwoju turystyki na obszarach wiejskich w Polsce (2015). Retrieved from: http://ksow.pl/fileadmin/user_upload/ ksow.pl/PROJEKTY_2015/Program_rozwoju_turystyki/ Program_rozwoju_turystyki_na_obszarach_wiejskich_wersja_ko\%C5\%84c.pdf (30.09.2018).

Rogalewski, O. (1974). Zagospodarowanie turystyczne. Warszawa: Wydawnictwa Szkolne i Pedagogiczne.

Sikorska-Wolak, I. (ed.) (2007). Turystyka w rozwoju obszarów wiejskich. Warszawa: Wydawnictwo SGGW.

Stanny, M. (2013). Przestrzenne zróżnicowanie rozwoju obszarów wiejskich w Polsce. Warszawa: IRWiR PAN.

Stasiak, A. (2013). Nowe przestrzenie i formy turystyki w gospodarce doświadczeń. Turyzm/Tourism, 23 (2), 65-74. DOI: https:// doi.org/10.2478/tour-2013-0012

Stasiak, A. (2015). Triada doświadczeń turystycznych i efekt „wow!” podstawą kreowania nowoczesnej oferty turystycznej. Prace Naukowe Uniwersytetu Ekonomicznego we Wrocławiu, 379, 332-347. DOI: https://doi.org/10.15611/pn.2015.379.32

Stasiak, A., Włodarczyk, B. (2013). Miejsca spotkań kultury i turystyki. In: B. Krakowiak, A. Stasiak, B. Włodarczyk (eds), Kultura i turystyka - miejsca spotkań (pp. 29-46). Łódź: ROTWŁ.

Sznajder, M., Przezbórska, L. (2004). Identification of rural and agri-tourism product and services. Roczniki Akademii Rolniczej w Poznaniu, CCCLIX, 166-177.

Zdon-Korzeniowska M. (2009). Jak kształtować regionalne produkty turystyczne. Teoria i praktyka. Kraków: Wydawnictwo Uniwersytetu Jagiellońskiego.

Article received:

12 July 2019

Accepted:

11 May 2020 